Виктор Трајановски, (Северна Македонија)

Институт за етнологија и антропологија

Природно-математички факултет

Универзитет „Св. Кирил и Методиј“ - Скопје

е-пошта: trajanovskiv@pmf.ukim.mk

\title{
СУФИЗАМ - ЕЗОТЕРИЧНАТА ИНТЕРПРЕТАЦИЈА НА ИСЛАМОТ
}

Апстракт: Во овој труд се претставени основните принципи на езотеричната страна на исламот, позната како суфизам. Неговата цел е запознавање на пошироката јавност со суфизмот и неговата основна доктрина, како и расветлување на овој езотеричен дел од исламот во обид да се намали недоразбирањето за одредени појави, бидејќи поради незнаење кон одредена култура или верска заедница лесно може односната група или индивидуа да биде предмет на омраза и нетолеранција.

Клучни зборови: етимологија, его, аскетизам, безусловна љубов, тарикати, Балкан, Македонија.

Одлуката за избор на оваа тема што ја обработува езотеричната страна на исламот, т.н. суфизам или тасавуф, е фактот на повеќевековното присуство на овој исламски феномен на македонското поднебје, изразено преку неговата практична димензија, односно во форма на дервишки редови или тарикати, кои заслужуваат одредено научно внимание.

Езотеричната страна на исламот или, како што одредени научници го нарекүваат, исламски мистицизам претставува навистина широка и комплексна тема. Свесни за широчината, сериозноста и комплексноста на суфизмот, нема овде да го анализираме во детали, бидејќ, како прво, би се изгубиле во неговата езотерија, а како второ, би ни било потребно многу повеќе време и простор за негово проучување и елаборирање. Понекогаш зборовите се недоволни или премалку за да се опише суштината на суфизмот затоа што ова учење се протега надвор од капацитетот на нашиот вокабулар. Некои од учените суфии ќе речат дека само преку живеењето

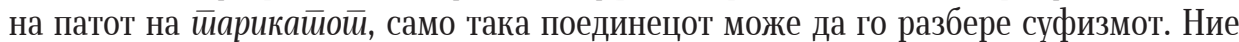
овде за суфизмот ќе дадеме општа слика, изнесувајќи само некои од значајните прашања на оваа тема со единствена цел запознавање и доближување на ова учење до пошироката јавност.

Езотеричната страна на исламот не може да се разгледува изолирано, како своевидна спиритуална дејност, туку мора да се земе во комплексна целина со прашањето на исламот и неговата цивилизација (Filipović 2005: 19). 
Исламскиот свет верува дека со Мухамед (570 - 632), божјиот пратеник, познат уште и како „совршен човек“ (тур. 凶nsan-ı Kâmil), започнала епохата на исламската култура и вера. Исламот тргнува од ставот дека Бог, за време на месецот рамазан во 610 година, со посредство на ангелот Џебраил, односно Гаврил, му ја објавил оваа религија на Мухамед, во пештерата Хира на планината Џабал ал Нур (планина на светлината) во близина на Мека.

Уште од самиот почеток, од времето на пратеникот Мухамед се појавува брз развој на индивидуалци и мали групи што го акцентирале аскетскиот живот и мистичниот приод кон директното знаење на Бог (Birge 1937: 13). Ваквото движење всушност ја сочинува езотеричната пракса во исламот наречена суфизам, термин широко прифатен во повеќе европски јазици, додека во исламската културна традиција се среќава под името тасавуф (арап. tasawwuf). Одредени научници се на стојалиште дека првите суфии може да се бараат меѓу асхабите, т.е. меѓу најблиските пријатели и приврзаници на пророкот Мухамед, кои постојано биле во неговата близина и најдобро биле упатени во исламската доктрина.

Развојот на тасавуфот продолжува во VIII век, кога суфиите почнуваат да се издвојуваат од другите муслимани по својата облека (едноставна волнена облека во бела боја) и начинот на живот, на што укажува и самиот термин „суфи“, кој првпат се појавил во втората половина на VIII век (Ćehajić 1986: 9-10).

Пред да продолжиме со анализа и објаснување што точно претставува суфизмот, најнапред да ја разгледаме етимологијата и историската семантика на зборот суфизам.

Постојат различни теории околу потеклото на зборот суфизам. Има истражувачи што го доведуваат овој збор во врска со чистотата (арап. сафа), мислејќи, притоа, на чистотата на душата, бидејќи првата задача на суфиите е да ги исчистат своите души од сите неморални особини (Џило 2010: 44).

Други, пак, терминот суфизам го доведуваат во врска со арапскиот збор „суф“ (șuff) што значи волна, што алудира на единствената облека од груба волна што ја носеле раните суфии, што пак ја симболизира желбата за испосништво, односно посветеност на духовен и скромен живот и одбегнување од материјалниот свет (Ćehajić 1986: 7-8). Во контекст на ова, за суфиите често може да се слушне и терминот факир или дервиш, едниот со арапско, а другиот со персиско потекло, и двата збора со значење сиромашен.

Трети сметаат дека терминот суфизам потекнува од зборот „ас-суфа“ (арап. as-suffa) што значи трем, простор пред влезот на џамијата, односно местото каде што често седела првата група приврзаници на тасавуфот (Abdul-Kadir 1998: 55). Тоа биле „луѓе од клупата“, односно посебна група пријатели на пратеникот Мухамед, кои живееле побожен и аскетски живот и избегнувале материјални уживања.

Некои теоретичари, пак, сметаат дека зборот суфи потекнува од зборот саф (apaū. as-saff) во значење 'редица', бидејќи суфиите, според нивното сфаќање, се во првата редица во однос на близината до Бог. И ден-денес е практика, во теќињата, најпредадените дервиши на одреден дервишки тарикат при молитва да стојат во првата редица (Џило 2010: 44). 
Во продолжение на овој труд ќе бидат изнесени елементите, односно составните делови или компоненти, т.е. ќе биде претставена структурата на суфизмот и на тој начин ќе се направи обид за дефинирање на значењето на самата доктрина.

Првата задача на суфиите е да ги исчистат своите срца од сите неморални особини. Имајќи го предвид значењето на срцето и неговата улога кај човекот, чесниот пратеник Мухамед, а.с., кажал: Во човечкото тело постои еден орган, ако е здрав, тогаш е здраво и целото тело, а ако се расипе, ќе се расийе и целото тело. Тоа е срцето! (Selvi 2013).

Водејќи се од оваа изрека на пратеникот Мухамед, суфиите сметаат дека болестите на срцето, како што се: агресивност, алчност, гнев, егоизам, завидливост, лицемерство, мрзливост, наклонетост кон измама, омраза, скржавост, тврдоглавост, прељуба и други неморални особини, се причина за оддалечување на верникот од Бог. За да се доближи верникот до Бог, што е главната цел на суфиите, првенствено мора да ги излечи овие болести на своето срце.

„Направив една куќа од светло, името му го надевав срце. Го оставев аманет во градниот кош на човекот, без оглед машко или женско, на човекот. Таа күќа од светло, кога е расположена је повисока од моите небеса“, рекол Господ. „Поширока од земјата, таа куќа од светло, кога е прегната, ни gлака не може gа йомине, йа куќa

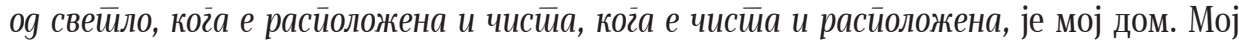
дом не се четири sидини, туку чистото срце на човекот. Е сега, тоа күќа од светло кога е валкана је вражји дом.“ Сега се јасни работите. Кај луѓето што се шејтан имат валкани срца, шејтаните. E туека нема Господ. Е туека е борбата. Да го чисти човекот срцето...

Најголемата препрека што се издига на патот до Бог претставува егото. Суфиите егото го сфаќаат како кила (лат. hernia), така што, колку повеќе егото се зголемува, толку болката е поголема. Ова суфиско начело за (не)постоење на егото можеме да го согледаме и од една кратка фантастична приказна добиена од страна на еден од моите соговорници, во која се претставува еден настан што тесно се поврзува со мираџот (арап. wal-Mi‘rāj), патување на пратеникот Мухамед до рајот. Овој настан е клучен за голем број суфии, бидејќи, според нив, претставува зародок на суфизмот, па, следствено на тоа, благодарение на овој настан пратеникот Мухамед се сфаќа како првиот суфија, „татко на суфизмот“, и е репер за секој што сака да пристапи на тој пат.

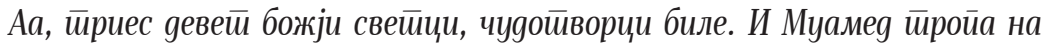

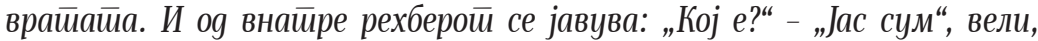

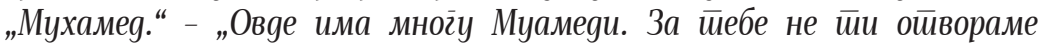

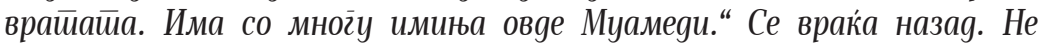

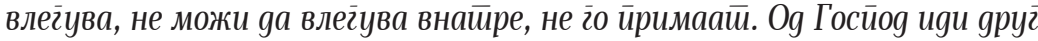

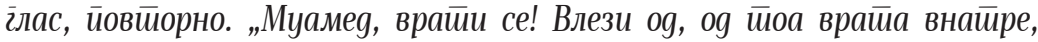

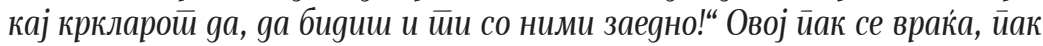

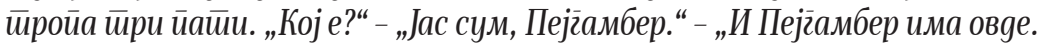

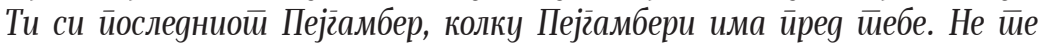

1 Сопствени теренски истражувања во Кичево. Соговорник Ејуп-баба, бекташки старешина во теќето X'д’р-баба во Кичево, на 75-годишна возраст, Албанец. 


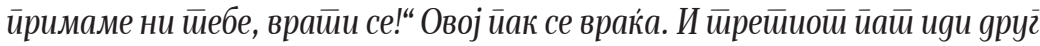
ілас. Џенаб-Алаах му вели: „Ко ќе ш̄ройниш, ко ќе иее ӣрашуваш, ко ќе

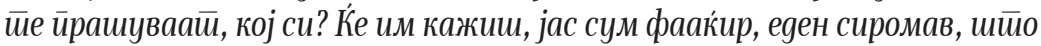

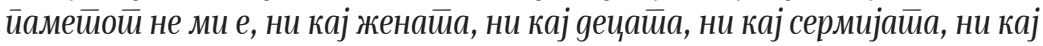

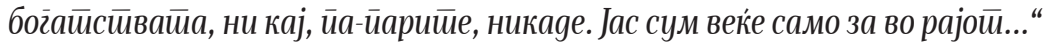

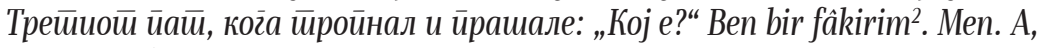
ако речи, бен, значи, аа, се креваш на големо, јас сум дирекйор, ама не, не е бен, мен... Ее, значи, ние сийе го уйойребуваме йој збор, факир. Значи gа не речиш Јac! Тој збор ако уйойребуваш, се креваш, се креваш наголемо.

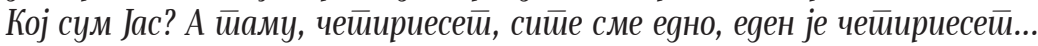

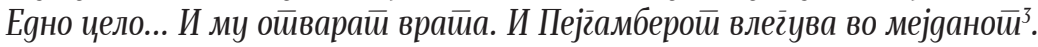

Од оваа приказна, покрај егото, можеме да забележиме уште еден составен

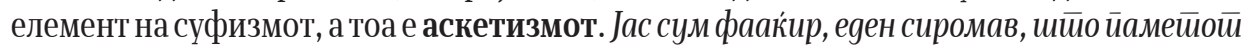

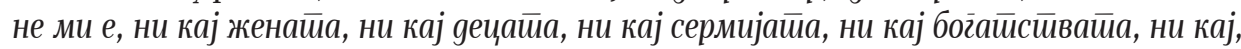
$\bar{u} a-\bar{u} а р и \bar{u} e$, никаgе 4 . За влез во рајот, односно за да се влезе и да се следи суфискиот пат и, на тој начин, да се достигне Бог, и човек да се соедини со Него, потребно е воздржување од повеќе земни задоволства.

Оттука произлегува една од најпроминентните карактеристики на дервишката побожност, а тоа е доброволното лишување од целиот имот или сопствеништво. Со други зборови, тоа подразбира откажување од материјалниот свет, со цел богатење и напредок во духовниот свет. Суфиите ќе речат: духовното и материјалното секогаш се во обратен сооднос, а тоа значи: колку човек материјално расте и се збогатува, исто толку духовно опаѓа и осиромашува (Karamustafa 1994: 14).

Всушност ваквото стојалиште или атрибут на дервишот - аскетско живеење во апсолутно сиромаштво - е појдовна точка за секој еден верник што пристапува во тарикатите или дервишките редови, но и перманентно начело со кое треба да се живее до крајот на животот.

Персискиот суфија Абу Јазид Бистами, познат и како Бајазид Бистами (починал 874 г. според христијанскиот календар), во суфиското учење го вовел методот на строг аскетизам и медитација со цел преку самоуништување да се дојде до Божјата суштина (Новаковић 2011: 484).

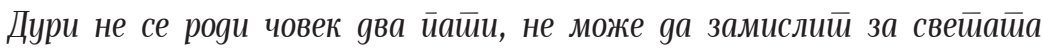

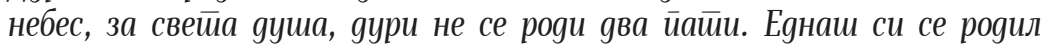

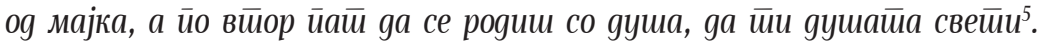

Повторното раѓање, кое не може да се замисли без посредство на муршидот, т.е. учителот, ја претставува победата постигната во борбата што суфијата мора да ја

2 Ben bir fâkirim, преведено на македонски јазик: јас сум еден сиромав.

3 Сопствени теренски истражувања во Канатларци, Прилепско. Соговорник дервиш Зекирија на 50-годишна возраст, Турчин.

4 Сопствени теренски истражувања во Канатларци, Прилепско. Соговорник дервиш Зекирија на 50-годишна возраст, Турчин.

5 Сопствени теренски истражувања во Кичево. Соговорник Ејуп-баба, бекташки старешина во теќето X'д'p-баба во Кичево, на 75-годишна возраст, Албанец. 
започне против самиот себе или против телесната душа, која е седиште на страстите. Оваа борба во исламот е позната како џихад.

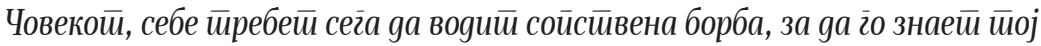

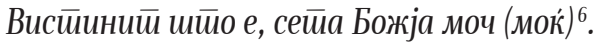

Кога зборуваме за суфизмот, не можеме да го прескокнеме името на големиот суфија Менсур ал Халаџ, надалеку познат по својата изјава: „Јас сум Вистина“ (арап. An’al-Haq), поради која подоцна ќе биде и егзекутиран. Ал Халаџ сметал дека целта на суфијата, па и на секое човечко битие, е соединување со Бога, кое се остварува преку патот на љубовта.

Соединувањето со Бог, по Халаџ, ја прави личноста совршена, света, зашто и самиот Бог зборува и живее во него (Џило 2010: 14).

Безрезервната и безусловна љубов кон Бог, пак, е уште една значајна компонента што е неизоставен дел од суфизмот. Оваа компонента во суфизмот ја има воведено Рабија ал Адевија, една од првите суфии жени, која живеела во VIII век, која ја истакнала апсолутната и ексклузивна љубов кон Бог како најголем инструмент на своето мистично искуство и потрага по Вистината. Безусловната љубов што ја пропагира Рабија ал Адевија е преточена во една нејзина прекрасна песна, која гласи:

О Господе,

Ако утре на Судниот ден

ме испратиш во Пеколот, јас ќе кажам таква тајна

што и самиот Пекол ќе побегне од мене

сѐ додека не биде илјада години оддалечен.

О Господе,

Што и да можеш да ми подариш од овој свет,

дај им го тоа на твоите непријатели.

Што и да сакаш да ми подариш од наредниот свет,

дај им го тоа на твоите пријатели.

За мене доволен си само Ти.

О Господе,

ако те славам Тебе

стравувајќи од пеколот,

изгори ме во него.

О Господе, ако те славам Тебе

со надеж за рајот, забрани ми ги неговите порти.

Но, ако те славам само заради Тебе самиот, нека ме благослови тогаш сјајот на Твоето лице, засекогаш!

(Sufi Poetry, http://www.spiritualfoundation.net/poetry.htm\#96914485)

6 Сопствени теренски истражувања во Кичево. Соговорник Ејуп-баба, бекташки старешина во теќето X'д’р-баба во Кичево, на 75-годишна возраст, Албанец. 
Љубовта е суштинска тема во суфизмот, прифатена од многу дервишки редови. Тоа е, всушност, вистинска причина за постоење на човекот. За овој принцип суфиите се потпираат на куранскиот стих: Кажи: „Ако го љубите Аллаха па, следете ме! Аллах ќе ве љуби и ќе ви ги прости гревовите ваши.“ Аллах е Простувач и Сомилосен! (Светиот куран 3:31).

Вистинската љубов е извор на сите доблести и единствениот пат да се стигне до Бог. Основата на љубовта не е да се сакаш самиот себе, но да се сака изворот на љубовта, Бог. Љубовта е постоење. Вистинската смрт доаѓ кога љубовта престанува да постои. Вистинската љубов не познава смрт.

Вљубеникот е оној човек што ја чува љубовта за Бог во неговото срце, а чија цел во животот е целосно соединување со Бог (On Love, http://bektashiorder.com/onlove).

Помеѓу раните суфии, со своето учење видно место зазема Ибн Араби. Основата на системот на Араби била доктрината наречена единство на постоењето (арап. wahdat al-wujud). Според оваа доктрина, Бог се смета за основа на секое битие, и не постои ништо друго освен Него. Сѐ што постои може да опстојува само благодарение на тоа што поседува еден аспект од Божествената реалност. И крајната и единствена цел е повторно враќање кон изворот и соединување со него.

Дервишот еднаш се доближил до неговиот учител Хоџа Ахмед Јесеви и го запрашал: „О учителу! Кажи ми кое е значењето на единството?“ Светецот не одговорил, но му рекол на дервишот да донесе голема коцка шеќер. Откако тој ја донесол, Хоџа Ахмед Јесеви го прашал: „Што е ова?“ - „Тоа е шеќер, мој үчителу“, рекол дервишот. Тогаш учителот му наредил да ја скрши коцката на три дела. Дервишот го направил тоа, и Ахмед Јесеви го прашал: „На што ти личат формите од овие три парчиња?“ Дервишот рекол: „Па првата ми личи на камила, втората на коњ, а последната личи на човек“. Тогаш светецот ги зел сите три парчиња шеќер и ги стиснал силно така што ги згмечил. Потоа го прашал дервишот: „Што се сега?“ Дервишот одговорил: „Тоа е шеќер, мој учителу“. Хоџа Ахмед Јесеви тогаш му објаснил: „Ова е единството. Ние сме тука денес и ќе бидеме тука утре, без оглед на тоа како нашите форми ќе се променат“ (From the Teachings of Haji Bektash Veli, http:// bektashiorder.com/teachings-of-haji-bektash).

Суфиите најмногу инспирации и инструкции добиваат од практиките и животот на пратеникот Мухамед, т.е. од сунетот, но уште повеќе од Куранот, кој го сметаат како главен инструмент за мистична врска со Бог.

За некои суфии рецитирањето на Куранот во текот на нивниот живот е нивно главно средство за концентрација во однос на Бога, кој пак е самата есенција на секој духовен пат (Лингс 2012: 29). Освен тоа, тие се свесни дека Куранот е дотек и одлив - дека дотекүва до нив од Бога и дека неговите реченици се чудесни знаци (ајет) што ќе ги одведат назад до Бога (Лингс 2012: 29).

Покрај својата теоретска страна, тасавуфот има и практичен аспект, тоа е тарикатот (арап. tariq, мн. turuq), кој се дефинира како пат, метод на приближување кон Бога (Ćehajić 1986: 18).

Веќе во X век се создаваат суфиски институции: рибат и завија на арапското, или ханеках на персиското подрачје. Сите овие термини означуваат суфиски центар 
или теќе. Како тенденција на овој развој, во почетокот на XII век, суфизмот во рамките на исламската култура се институционализира во форма на дервишки редови или тарикати (Џило 2010: 219), кои биле врзани за еден учител, основач (пир), чие име го носи односниот ред, го усвојува неговиот метод на обука, го користи неговото мистичко искуство и ги следи правилата на суфискиот живот што тој ги зацртал и до кои се држи. Тоа негово учење се пренесува по пат на континуиран ланец (силсила), а шејховите што се создаваат внатре во одреден дервишки ред стануваат духовни наследници на основачот на редот (С́ehajić 1986: 19).

Дервишки редови, односно тарикати што егзистирале низ историјата се: бајрами (тур. bayramiyye), јесеви (тур. уeseviyye), кадири (арап. qadiriyya), кубреви (арап. kubrawiyya), мевлеви (тур. mevleviye), накшибенди (арап. naqshbandì), ниматулахи (пер. nimatollahi), рифаи (арап. rifa'iyya, тур. rüfai), садии (тур. sadiyye), сухраверди (арап. suhrawardiyya), халвети (арап. khalwatiyya), хамзеви, шазили (арап. shadhili), бекташи (bektaşi) и други.

Во секој дервишки ред, односно тарикат, постојат четири порти низ кои верникот треба да помине за конечно соединување со Реалноста. Овие четири порти се: шеријат (закон), тарикат (пат), марифет (спознание) и хакикат (Божествена реалност).

За да се оствари тој духовен пат, мора да се почне од некаде и да се заврши

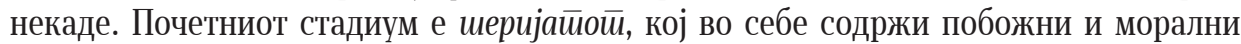

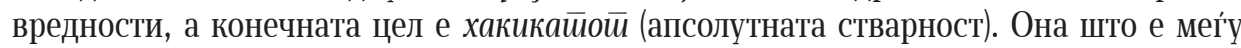
нив е патот, патека по која се минува, која претставува спојка на овие две составки на суфискиот живот (Џило 2010: 71).

Метафорички суфискиот пат често е опишан како орев, чија зелена обвивка го претставува шеријатот. Тврдата кора го претставува тарикатот. Јатката што се наоѓa внатре во кората е марифетот, а вкусот што е невидлив, но сепак присутен хакикатот, т.е. Божјата реалност. Што значи, за да се стигне до Реалноста, мора прво да се скине оревот, потоа да се излупи, да се скрши и на крајот да се изеде.

Секоја порта ја сочинуваат одредени степени или фази, маками, како што се: одрекување, сиромаштво, воздржување, страдање, покајание, преобраќање, трпеливост, кои преку духовно-воспитно-образовна активност треба да се поминат и да се стекнат одредени психолошки состојби наречени ахвал, како што се: задоволство, сигурност, блискост, љубов, спознание. На тој начин се отстранува завесата што ја крие душата од Вистината, и конечно душата на верникот ќе стигне до Бог и ќе се соедини со Него.

Како плод на искуствата на бројни големи суфии, тарикатите се занимаваат токму со оваа практична реализација од различни модалитети на ритуали и молитви, зикр, а крајната намера е човековиот дух да се ослободи од ропството, сладострасноста и маните и да се украси со доблести. Значи, редот - тарикатот - е повеќе „култивација на религиозното искуство“ или „пат на прочистување“ (Trimingham 1971: 2).

Овие дервишки редови претставуваат систем заснован на релацијата учител и ученик, кои се изразуваат со арапските термини мурииg (учител, водач) и муриg (ученик, кандидат). Според тоа, редот е практичен метод за водење и обучување на ученикот од страна на шејхот, како водач што му ги трасира патот, мислите, чувствата 
и акциите и го води низ фази (маками) во интегрална поврзаност со психолошките искуства или состојби (ахвал) кон интуитивно спознание на Божествената реалност (хакикат) (Trimingham 1971: 3-4).

За да се спроведе оваа обука, биле создадени теќињата. Тоа се места каде што се вршела, се анализирала и се доживувала исламската суфиска мисла и подоцна му се претставувала на населението. Тие се институции на тасавуфот и составен дел од исламската култура во кои живеат или престојуваат следбениците на тарикатот (муриди, мухиби), кои под материјална и смисловна контрола на еден одреден шејх настојуваат да ги разубават нивниот морал и етика врз основа на исламските суфиски начела (Изети 2008: 87).

Непобитна вистина е дека теќињата низ исламската историја влијаеле на заживувањето на исламските начела, но тие, истовремено, покажале голем успех и во ширењето на исламот. Исламизацијата на одредени делови на Балканот е направена преку теќињата и чесните шејхови што дејствуваат во нив (Изети 2008: 88-89).

Доколку претходно изложените факти во овој труд се инкорпорираат во една дефиниција што ќе ја окарактеризира оваа доктрина како значаен духовен феномен, таа би гласела: суфизмот претставува внатрешна, езотерична димензија на исламот, начин на живот насочен кон остварување на Божјата вистина, осносно воспитување со цел приближување, соединување и единство со Апсолутот (Бог), што

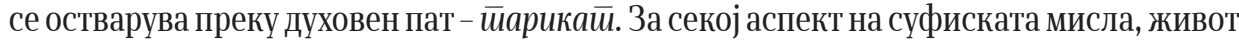
и идеал може да се најде основа во Божјата објава - Куранот и во праксата на божјиот пратеник Мухамед. Под водство на духовен учител, муршия, треба да се воспита душата, да се исчисти срцето од сите неморални особини, односно човековиот дух да се ослободи од сладострасноста и маните и да се закити со доблести. Сето тоа е возможно само преку патот на љубовта, т.е. преку безрезервната и безусловна љубов кон Бог.

\section{Суфизмот на Балканот и во Македонија}

Првите навестувања за присуство на одредени дервишки редови на Балканот, а со тоа и во Македонија, според одредени претпоставки (Birge 1937: 51; Изети 2008; Носа 2016: 73-100), се појавиле со поединци мисионери што доаѓале на Балканот уште пред османлиските освојувања, со што создале поволни услови за прифаќање на исламот на овие простори.

Кога зборуваме за присуството на дервишите мисионери на Балканот пред османлиските освојувања, неминовно е да се спомне името на мисионерот Сар' Салтук, кој, според преданијата, одиграл значајна улога во ширењето на суфизмот на Балканот (Конеска 2009: 231).

Сар' Салтук се смета како патрон, заштитник на муслиманите, кој го претставил и запознал исламот со Балканот (İnalcık 2016: 13). Повеќето балкански тарикати го сметале Сар' Салтук како припадник на нивниот тарикат. Сепак, Сар' Салтук се здобил со поголемо почитување меѓу бекташите и, на Балканот, повеќе е познат како припадник на бекташкиот тарикат (Изети 2008: 102). 
Некои автори сметаат дека улогата на овие мисионери била планирана и остварувана со цел колонизирање на христијанските земји. Но, според други автори, овие претпоставки се без посериозни историски докази, се темелат главно на легенди и претставуваат фолклорна епика (Norris 1993: 89; Иналџик 2004; Паликрушева 2001: 7-12).

Од друга страна, пак, она што со сигурност може да се потврди, поткрепено со историски докази, е присуството на бројните дервишки тарикати на подрачјето на Балканот од османлиската доба, што во континуитет се одржало до денешни дни. Преминувајќи на Балканскиот Полуостров, Османлиите со себе ја донеле својата религија, сунитскиот ислам, но, исто така, паралелно со сунитскиот ислам, на Балканот навлегол и суфизмот, содржан во учењето на разните дервишки редови (Стојановски 1998; Čolić 1995: 6; Nehri 2015: 78; Clayer 2011: 2). Познато е дека дервишките редови веќе од самиот почеток на османлиската власт во нашите краеви (XIV век) заземаат активно учество во процесот на формирање населби и ширење на исламот и исламско-ориенталната култура (С́еhajić 1986: 5).

На Балканот, кога ќе се спомнат суфиските редови или тарикати, главно се добива претстава на заштитници, бранители и пропагатори на исламот. Придонесот што го дале суфиските шејхови (како во минатото така и денес) и нивните следбеници организирани во суфиски, дервишки (х)алки е огромен (Abiva 2005: 194).

Основачите на теќињата, шејховите, и нивните дервиши, поради своето отворено и хумано однесување, биле многу омилени кај народот. Помеѓу многубројните активности што ги вршеле, треба посебно да се истакнат моралното воспитување, бесплатното делење храна на сиромашните, грижата за ужалените и луѓето што имале проблеми, давањето помош на немоќните. Сите луѓе, без разлика на раса, пол, етничка или верска припадност, можеле без каков било проблем во теќињата да најдат храна и засолниште (Ratkovс̌ić 2014: 55).

Суфизмот, изразен преку многубројните дервишки редови, честопати ги прифаќал доминантните карактеристики на локалната средина, па така не ретко се создавал еден сублимат, една симбиоза на исламски (тарикатски) и локални (балкански) елементи, што придонело за доближување на дервишките редови до локалното население и полесно прифаќање на овој дел од исламот од страна на домицилното население.

Влијанието на дервишките редови се ширело од суфиските центри - теќиња, кои постоеле во повеќе градски населби и во многу села во Македонија, Босна и Херцеговина, Србија, Албанија, Бугарија, Грција и на Косово. Во споменативе области биле раширени разни дервишки редови, како што се: мевлеви, накшибенди, халвети, кадири, рифаи, бекташи, хамзеви и др., кои давале одреден тон не само на религиозна туку и на општествена и културна атмосфера во споменатите области (Ćehajić 1986: 5).

Моќта на влијанието и нивната функција во балканските општества е видлива по бројот и разноликоста на тарикатите што со векови дејствувале на ова подрачје (и сѐ уште дејствуваат). Најбројни и најраспространети тарикати за време на османлиското владеење биле редовите халвети (khalwatiyyah) и бекташи (bektashiyуah). Овие два тарикати доминирале на османлискиот Балкан за целото време на османлиската ера (Abiva 2005: 194). 
Редовите накшибенди (naqshbandiyyah), кадири (qadiriyyah) и рифаи (rifa'iyyah) следеле веднаш зад нив по значењето, во однос на бројот на следбеници и територијалната застапеност. Изненадувачки, сите споменати редови некако успеале да останат до денес и прилично да ја зачуваат популарноста.

Неколку други тарикати, како мевлеви, бајрами, мелами, саgии, иалвешии, шазили и беgеви, сепојавилево различни временскипериоди и со различен интензитет за време на отоманската доба, дел од нив се свеле до степен на исчезнување, а некои од нив наполно исчезнале (Abiva 2005: 194-195).

Слабеењето на суфиските редови на Балканот и во Македонија се одвивало во склад со опаѓањето на влијанието на османлиската власт. Секако, негативно влијание врз намалувањето на бројот на тарикати и теќиња на овие простори имале Балканските војни, двете светски војни и други историско-политички настани.

Тарикатите во Македонија најмногу биле изложени на иселување на мүслиманската популација во Турција. До шеесеттите години на XX век, многу теќиња на подрачјето од средна и источна Македонија, кои некогаш ги населувале Турци, се опустошени како резултат на преместувањето на населението. Особено тука треба да се спомне „Договорот за слободна емиграција“, склучен помеѓу ФНР Југославија и Република Турција, во 50-тите години на XX век, познат уште и како „Џентлменски договор“, со кој се предвидува иселување на турското население од ФНР Југославија во Република Турција. Овој договор бил судбоносен за тарикатскиот живот и теќињата во Македонија.

Денес уште може да се пронајдат нечепнати турбиња на шејхови во подрачјата каде што муслиманите не сочинуваат никаков фактор во демографска смисла. Сепак, локалното христијанско население на тие места сѐ уште им укажува посебна почит и внимание.

И покрај ваквите случувања што негативно се одразиле врз тарикатскиот живот во Македонија и на целиот Балкански Полуостров, сепак одредени дервишки редови со своите теќиња успеале да ги пребродат сите бури низ историјата што го зафатиле суфизмот и да продолжат активно да ја практикуваат езотеричната страна на исламот, а со тоа да бидат живи сведоци на повеќевековниот тарикатски живот во Македонија и на Балканот. 


\section{ЕтноАнтропоЗум}

\section{Литература}

Изети, Метин. 2008. Тековите на тесавуфот. Тетово.

Иналџик, Халил. 2004. Османската Империја: класично доба 1300-1600. Скопје.

Конеска, Елизабета. 2009. „Преглед на бекташкиот дервишки ред во Р. Македонија“. Балканите между традицията и модерноста. Административни, социалноикономически и културно-просветни институции в балканските провинции на Османската империя (XVIII-XIX век). София.

Лингс, Мартин. 2012. Што е суфизам? Скопје.

Новаковић, Драган. 2011. „Исламски мистицизам - суфизам“. Зборник Матице српске за друштвене науке, 6р. 137, 481-494. http://www.doiserbia.nb.rs/img/doi/03525732/2011/0352-57321137481N.pdf, пристапено на: 21.7.2019.

Паликрушева, Галаба. 2001. „Преданија за дрвишките редови кај Турците и Македонците“. Македонски фолклор 56/57. Скопје, 7-12.

Светиот куран 3:31, Али Имран (Семејството Имраново), http://kuran-na-makedonski. net/\#3:31, пристапено на: 5.7.2019.

Стојановски, Александар (ред.). 1998. Историја на македонскиот народ II: Македонија под турска власт (од XIV до крајот на XVIII век). Скопје.

Џило, Хасан. 2010. Филозофија на суфизмот. Скопје.

Abdul-Kadir, Isa. 1998. Istine o tesavvufu. Sa arapskog originala preveo: Ahmed Mešić. Tuzla.

Abiva, Hüseyin. 2005. „Kratak pregled sufizma na Balkanu“. Znakovi vremena. Vol. 8, br. 26/27. Sarajevo, 192-208.

Birge, John Kingsley. 1937. The Bektashi Order of Dervishes. London.

Clayer, Nathalie. 2011. „Muslim Brotherhood Networks in South-Eastern Europe“. European History Online (EGO), Mainz 2011-05-11. http://www.ieg-ego.eu/clayern-2011-en, пристапено на: 6.4.2019. 
Čolić, Ljiljana. 1995. Derviški redovi muslimanski: Tekije u Skoplju. Beograd.

Ćehajić, Džemal. 1986. Derviški redovi u jugoslovenskim zemljama sa posebnim osvrtom na Bosnu i Hercegovinu. Sarajevo.

Filipović, Nedim. 2005. „Tasawwuf - Islamski misticizam“. Znakovi vremena. Vol. 8, br. 28. Sarajevo.

From the Teachings of Haji Bektash Veli, http://bektashiorder.com/teachings-of-hajibektash, пристапено на: 6.4.2017.

Hoca, Fadıl. 2016. „Balkanlar'da İslamiyet'in Yayılmasında Sarı Saltuk'la İlgili Efsaneler ve Rivayetlerin Önemli“. Balkanlarda Islam: Miadı Dolmayan Umut 2. Muhammet Savaş Kafkasyalı (Editör), 73-100.

İnalcık, Halil. 2016. „Türkler ve Balkanlar“. Balkanlarda Islam: Miadı Dolmayan Umut 2. Muhammet Savaş Kafkasyalı (Editör), 9-39.

Karamustafa, Ahmet T. 1994. Derviş groups in the islamic later middle period 1200-1550. Salt Lake City.

Nehri, Aydinçe. 2015. „Balkanlarda Tarikatlar; Makedonya'daki Halvetîliğe Genel Bakış“. Eskişehir Osmangazi Ünivezirtesi İlahiyat fakultesi Dergisi II, 75-90.

Norris, H. T. 1993. Islam in the Balkans: Religion and Society Between Europe and the Arab World. Colombia.

On Love, http://bektashiorder.com/on-love, пристапено на: 6.4.2017.

Ratkovčić, Rosana. 2014. „Prisutnost derviša na području Slavonije i Srijema u vrijeme osmanske vladavine“. Scrinia slavonica 14. Slavonski Brod, 53-77.

Selvi, Dilaver. 2013. Mjesto tesavufa и islaти, според хадисите на Bukhari, Muslim, Ibn Madže. http://kosusufije.blogspot.com/2013_08_01_archive.html, пристапено на: 23.7.2018.

Sufi Poetry, http://www.spiritualfoundation.net/poetry.htm\#96914485, пристапено на: 6.4.2017.

Trimingham, J. Spenser. 1971. The Sufi Orders in Islam. Oxford. 